ББК 63.4

$$
\begin{gathered}
\text { Организация конференции и издание материалов проведены } \\
\text { при финансовой поддержке Российского фонда фундаментальных исследований, } \\
\text { проект № 19-09-20008 }
\end{gathered}
$$

Утверждено к печати Ученым советом ИИМК РАН

Редакционная коллегия тома II: А. В. Поляков, Е. С. Ткач (отв. редакторы), М. Т. Кашуба, Л. Б. Кирчо, Е. А. Черлёнок, В. Я. Стёганцева, А. И. Климушина

Рещензенты: д. и. н. Л. Б. Вишняцкий, д. и. н. А. А. Выборнов

Программный комитет конференции: академик РАН, д. и. н., проф. М. Б. Пиотровский (Государственный Эрмитаж, почетный председатель); д. и. н. В. А. Лапшин (ИИМК РАН, председатель); д. и. н. А. В. Головнёв (МАЭ РАН, сопредседатель); д. и. н. В. А. Дергачёв (Высшая антропологическая школа, Молдова, сопредседатель); д. и. н. И. Ф. Попова (ИВР РАН, сопредседатель); академик АН Республики Узбекистан, д. и. н., проф. Э. В. Ртвеладзе (сопредседатель); к. и. н. А. В. Поляков (ИИМК РАН, зам. председателя); к. и. н. В. А. Алёкшин (ИИМК РАН, зам. председателя); д. и. н. Ю. Е. Берёзкин (МАЭ РАН); Dr., Prof. Н. Бороффка

(Германский археологический институт, Германия); В. С. Бочкарёв (ИИМК РАН);

Dr. Э. Кайзер (Свободный университет Берлина, Германия); к. и. н. М. Т. Кашуба (ИИМК РАН); д. и. н. Л. Б. Кирчо (ИИМК РАН); к. и. н. А. В. Кияшко (Южный федеральный университет); к. и. н. П. Ф. Кузнецов (СГСПУ); к. и. н. Н. М. Малов (СНИГУ); к. и. н. В. П. Никоноров (ИИМК РАН); Ю. Ю. Пиотровский (Государственный Эрмитаж); д. и. н., проф. Д. Г. Савинов (Институт истории СПбГУ); к. и. н. В. Н. Седых (Институт истории СПбГУ); к. и. н. Н. Н. Скакун (ИИМК РАН); к. и. н. Н. Ф. Соловьёва (ИИМК РАН); к. и. н. А. И. Торгоев (Государственный Эрмитаж); к. и. н. Е. А. Черлёнок (Институт истории СПбГУ)

Организационный комитет конференции: к. и. н. А. В. Поляков (ИИМК РАН, председатель); к. и. н. В. А. Алёкшин (ИИМК РАН, зам. председателя); В. С. Бочкарёв (ИИМК РАН); к. и. н. М. Т. Кашуба (ИИМК РАН); д. и. н. Л. Б. Кирчо (ИИМК РАН);

А. И. Климушина (ИИМК РАН, отв. секретарь); к. и. н. В. П. Никоноров (ИИМК РАН); Ю. Ю. Пиотровский (Государственный Эрмитаж); В. Я. Стеганцева (ИИМК РАН); В. В. Терёхина (ИИМК РАН, МАЭ РАН, отв. секретарь); к. и. н. Е. С. Ткач (ИИМК РАН); И. Ж. Тутаева (Государственный Эрмитаж); к. и. н. Е. А. Черлёнок (Институт истории СПбГУ)

Древности Восточной Европы, Центральной Азии и Южной Сибири в контексте связей и взаимодействий в евразийском культурном пространстве (новые данные и концепции): Материалы Международной конференции, 18-22 ноября 2019 г., Санкт-Петербург. Т. ІІ. Связи, контакты и взаимодействия древних культур Северной Евразии и цивилизаций Востока в эпоху палеометалла (IV-I тыс. до н. э.). К 80-летию со дня рождения выдающегося археолога В. С. Бочкарёва. - СПб.: ИИМК РАН, Невская Типография, 2019. - 287 с.

ISBN 978-5-907053-35-9

DOI 10.31600/978-5-907053-35-9 


\title{
CULT COMPLEXES OF THE SETTLEMENT OF MALAYA SOPKA \\ OF THE TURN BETWEEN THE MIDDLE AND LATE BRONZE AGE
}

\author{
Alexander I. Yudin ${ }^{\star}$, Yuriy E. Kochetkov** \\ ${ }^{*}$ Limited liability Company "LRT-Heritage", Saratov, Russia; ${ }^{* *}$ Autonomous nonprofit organization \\ "Research center for the preservation of cultural heritage", Saratov, Russia
}

Keywords: Bronze Age, Babino culture, ritual complex, cult place.

In 2017, the authors investigated the settlement of Malaya Sopka in the Oktyabrsky district of Rostov region throughout the area of $10050 \mathrm{sq}$. m. Remains of dwellings, outbuildings, pits and hearths characteristic of settlements were here absent although the greater area of the site had been excavated. Noteworthy is the rather small amount of ceramics and bones; the layer under study yielded very scarce finds as compared with the cultural layers at other settlements of the Bronze Age.

Of most interest are ten ritual complexes in the form of ditches of different plan: rings, double rings, sub-rectangular, semi-oval, etc. Finds in the lower part of the cultural layer, which is associated with construction of the ritual complexes, are dated to the boundary between the Middle and Late Bronze Age, i.e. the late Babino culture. The site under study possibly can be interpreted as a special worshiping area, i.e. a cult place or a sanctuary.

\section{МОГИЛЬНИК БРОНЗОВОГО ВЕКА КАМЕННЫЙ АМБАР-5 В ЮЖНОМ ЗАУРАЛЬЕ (ТИПОЛОГИЯ, ХРОНОЛОГИЯ, ГЕНЕТИКА ${ }^{1}$}

\author{
А. В. Епимахов \\ Институт истории и археологии Уральского отделения РАН, \\ Южно-Уральский государственный университет, Екатеринбург, Россия \\ DOI: 10.31600/978-5-907053-35-9-246-247
}

Ключевые слова: палео-ДНК, относительная и абсолютная хронология, бронзовый век, Южный Урал, синташтинские памятники, срубная культура.

Могильник Каменный Амбар-5 в Южном Зауралье - один из наиболее комплексно исследованных памятников бронзового века региона. Он получил известность благодаря синташтинским материалам (Епимахов 2005), но в последние годы они были дополнены срубными. Это создало новые возможности для мультидисциплинарного исследования, которые частично реализованы (серийное радиоуглеродное датирование, комплексный анализ антропологических и вещественных находок, стабильных изотопов, палео-ДНК и др.) (Дегтярёва 2010; Hanks et al. 2018; Judd et al. 2018). Погребения двух культурных традиций обнаружены в разных курганах в пределах одной площадки.

Первая группа включает четыре кургана, 37 могильных ям, более 100 погребенных. Стратиграфические наблюдения позволяют выделить этапы относительной хронологии. Типологический анализ демонстрирует разнородность керамического комплекса, который частично согласуется со стратиграфией. Обрядность характеризуется вариативностью, обилием инвентаря и жертвоприношений домашних животных. Для памятника имеется серия из 16 радиоуглеродных дат и генетические определения 50 индивидов. Большинство калиброванных дат приходится на узкий интервал (первая четверть II тыс. до н. э.). Срубная часть представлена четырьмя курганами, 24 могильными ямами, 26 индивидами (преимущественно детьми младших возрастов). Материалов для установления относительной

${ }^{1}$ Работа выполнена при финансовой поддержке Минобрнауки РФ, государственное задание 33.5494.2017/БЧ «Пограничье культурных миров (Южный Урал от древности до нового времени)». 
хронологии нет. Обрядность унифицирована, количество инвентаря, за вычетом керамической посуды, невелико, число индивидуальных находок и жертвоприношений, ассоциированных с погребениями, минимально.

Анализ палео-ДНК синташтинской части памятника выявил группы кровных родственников. Кроме того, шесть индивидов имели состав ДНК, отличный от основного ядра. Эта гетерогенность частично согласуется с характером вариативности материальной культуры и относительной хронологией. Генетический состав отложившейся группы сближается со срубными материалами (захоронения взрослых) этого же могильника. Структура ДНК детей из срубных курганов сходна с основной синташтинской серией.

Датировки двух серий формируют практически идентичные интервалы калиброванных значений, что дублируется сходством ряда черт керамического комплекса поздней части синташтинских захоронений со срубными. При этом погребальная обрядность демонстрирует радикальные различия по основным параметрам. Варианты интерпретации этой суммы фактов различны, но ни один из них не укладывается в схему плавной эволюции культурных традиций в начале периода поздней бронзы. Налицо картина сложного взаимодействия носителей разных культурных традиций, предполагающего их преемственность и/или частичную синхронизацию.

\section{Литература}

Дегтярёва А. Д. 2010. История металлопроизводства Южного Зауралья в эпоху бронзы. Новосибирск.

Епимахов А. В. 2005. Ранние комплексные общества Севера Центральной Евразии (по материалам могильника Каменный Амбар-5). Кн. 1. Челябинск.

Judd M. A., Walker J., Ventresca Miller A., Rajev D., Epimakhov A., Hanks B. 2018. Life in the fast lane: settled pastoralism in the Central Eurasian Steppes during the Middle Bronze Age. In: American Journal of Human Biology. Vol. 30 (4). P. 1-23. DOI: 10.1002/ajhb.23129.

Hanks B. K., Ventresca Miller A., Judd M., Epimakhov A., Razhev D., Privat K. 2018. Bronze Age Diet and Economy: New Stable Isotope Data from the Central Eurasian Steppes (2100-1700 BC). In: Journal of Archaeological Science. Vol. 97. P. 14-25.

\section{BRONZE AGE CEMETERY OF KAMENNY AMBAR-5 IN THE SOUTHERN TRANS-URALS (TYPOLOGY, CHRONOLOGY, GENETICS)}

\section{Andrey V. Epimakhov \\ Institute of History and Archeology of the Ural Branch of RAS; South Ural State University, Yekaterinburg, Russia}

Keywords: paleo-DNA, relative and absolute chronology, Bronze Age, Southern Urals, Sintashta sites, Srubnaya culture.

The cemetery of Kamenny Ambar-5 (Southern Trans-Urals) of the Bronze Age includes kurgans of the Sintashta and Srubnaya cultures. Despite the radical differences in the funeral rites and material culture, these objects have a number of similar features. Firstly, the stratigraphically late burials of the Sintashta kurgans contain ceramic vessels with Srubnaya features. Secondly, calibrated radiocarbon dates indicate a single time interval (first quarter of the $2^{\text {nd }}$ millennium cal BC). Finally, paleogenetic analysis has revealed the internal heterogeneity for the Sintashta and Srubnaya series. At the same time, groups of outliers find correspondences in series of different cultures: some of the Sintashta individuals resemble Srubnaya individuals and vice versa. Thus, the results of multidisciplinary research show a picture of a complex interaction of different cultural traditions, at least partially synchronous during the beginning of the late Bronze Age. 